\title{
Hypertrophic Olivary Degeneration Secondary to Head Trauma
}

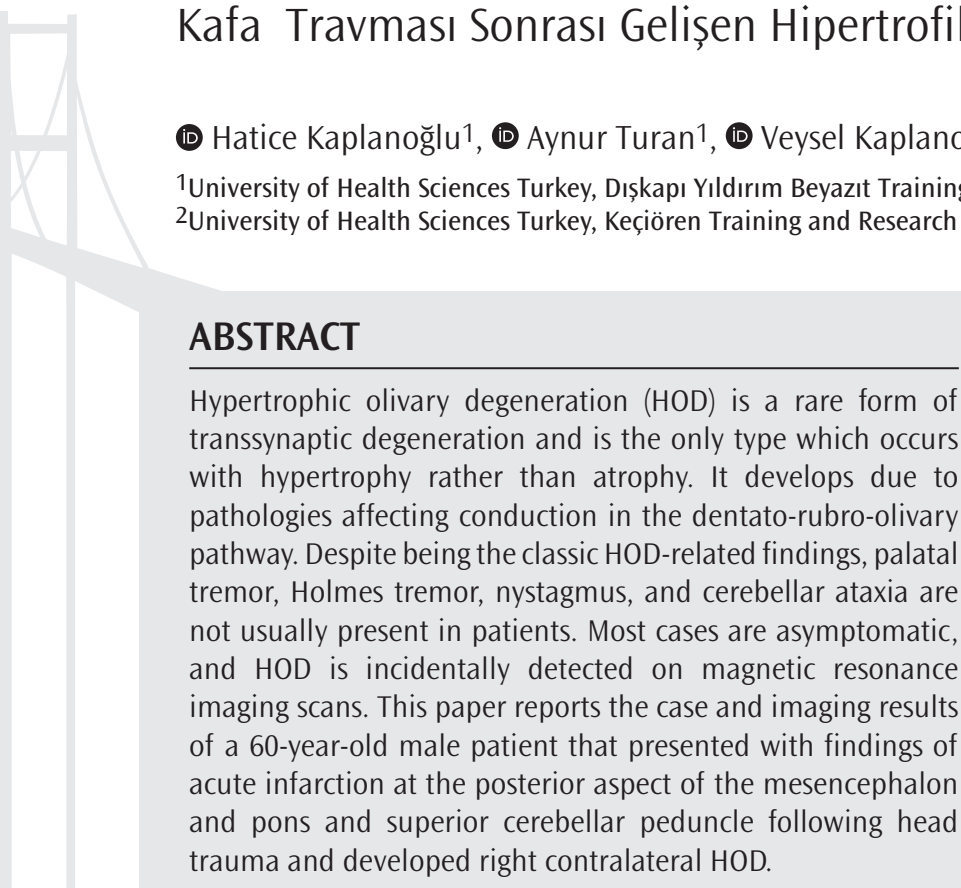

Keywords: Hypertrophic olivary degeneration, GuillianMollaret triangle, dentato-rubro-olivary pathway, MRI

\section{öz}

Hipertrofik olivar dejenerasyon (HOD) transsinaptik dejenerasyonun nadir görülen bir formu olup atrofi yerine hipertrofiyle presente olan tek dejenerasyon tipidir. Dentatorubro-olivar yoldaki iletimi etkileyen patolojiler sonucu ortaya çıkmaktadır. Palatal tremor, Holmes tremor, nistagmus ve serebellar ataksi klasik olarak HOD ile ilişkili bulgulardır, ancak bunlar genellikle hastalarda mevcut değildir. Hastaların çoğu asemptomatiktir ve manyetik rezonans görüntüleme taramalarında insidental olarak bulunabilir. Burada 60 yașında erkek hastada, kafa travması sonrası solda pons-mezensefalon posteriorunda ve süperior serebellar pedinkülde akut enfarkt oluşan ve sonrasında ortaya çıkan sağ kontralateral hipertrofik olivar dejenerasyon görüntüleme bulguları ile birlikte sunulmaktadır.

Anahtar Kelimeler: Hipertrofik olivar dejenerasyon, GuillianMollaret üçgeni, dentato-rubro-olivar yolak, MRG.

\section{Introduction}

Hypertrophic olivary degeneration (HOD) is a transsynaptic degeneration resulting from disruption of the communication between the dentate nucleus of the cerebellum and the inferior olivary nucleus. The area forming this cycle is known as the Guillain-Mollaret triangle (1). HOD usually develops secondary to destructive events occurring in the brainstem or cerebellum, including this triangle. The dentato-rubral and rubro-olivary pathways are impaired by the denervation of olivary neurons (2). Hypertrophy of the target organ due to transneuronal degeneration is specific to the inferior olivary nucleus. This degeneration was first described by Guillain and Mollaret in a case of palatal myoclonus that developed following an isolated lesion occupying the inferior cerebellar peduncle (1). Events that are most commonly known to cause HOD include stroke, trauma, tumours, brain surgery interventions, and gamma knife surgical treatment of brainstem cavernoma (2). In this paper, we present the radiological findings of HOD that developed in the olivary nucleus following trauma. Informed consent form was taken from the patient.

\section{Case Report}

A 60-year-old male patient was brought to our emergency department with head trauma due to a fall. His history included ethanol use and mental retardation. On examination, the patient was cooperative, but his orientation was limited and dysphasic. The pupils were isochoric, the four extremities were moving, and the vitals were stable. Cranial computed tomography revealed haemorrhage in the left parietal lobe and fracture lines in the mastoid and squamous parts of the right temporal bone (Figure 1). Cranial and diffusion magnetic resonance imaging (MRI) showed subdural haemorrhage in the left parietal region and areas of acute, diffusion-restricted, hyperintense infarction in the posterolateral regions of the left mesencephalon and pons and at the level of the superior cerebellar peduncle on T2-weighted images (Figure 2). There was subarachnoid haemorrhage in the intraventricular area and left cerebral hemisphere. The patient's treatment was initiated in the intensive care unit and his symptoms almost completely improved in about one month. On the control MRI, an infarct area in the late

Address for Correspondence/Yazışma Adresi: Hatice Kaplanoğlu MD, University of Health Sciences Turkey, Dışkapı Yıldırım Beyazıt Training and Research Hospital, Clinic of Radiology, Ankara, Turkey

Phone: +90 3125084443 E-mail: hatice.altnkaynak@yahoo.com.tr ORCID ID: orcid.org/0000-0003-1874-8167

Received/Geliș Tarihi: 11.01 .2020 
subacute process was observed in the posterolateral regions of the left mesencephalon and pons, which also affects the superior cerebellar peduncle and is surrounded by haemosiderin pigment. At the right medulla oblangata level, there was a nodular lesion in the olivary nucleus, which was hyperintense on T2-weighted and fluid-attenuated inversion recovery (FLAIR) images and showed no restriction in diffusionweighted images. This lesion was evaluated as a HOD (Figure 3). The patient was followed up by the neurology outpatient clinic.

\section{Discussion}

HOD is a type of transsynaptic degeneration characterised by hypertrophy of the inferior olivary nucleus in response to any damage to the dentatorubro-olivary pathway. These formations are interconnected through the superior cerebellar peduncle, central tegmental tract, and inferior cerebellar peduncle (3). This structure is a component of the reflex arc

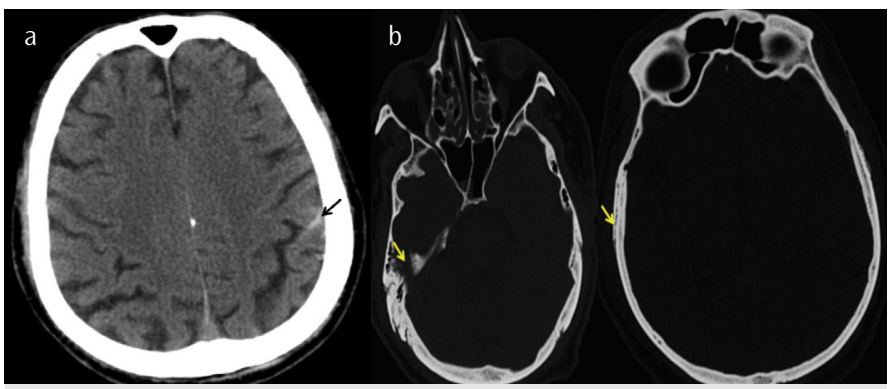

Figure 1. Cranial computed tomography showing a. haemorrhage in the sulci in the left parietal lobe (black arrow) and b. fracture lines in the mastoid and squamous parts of the right temporal bone (yellow arrows)
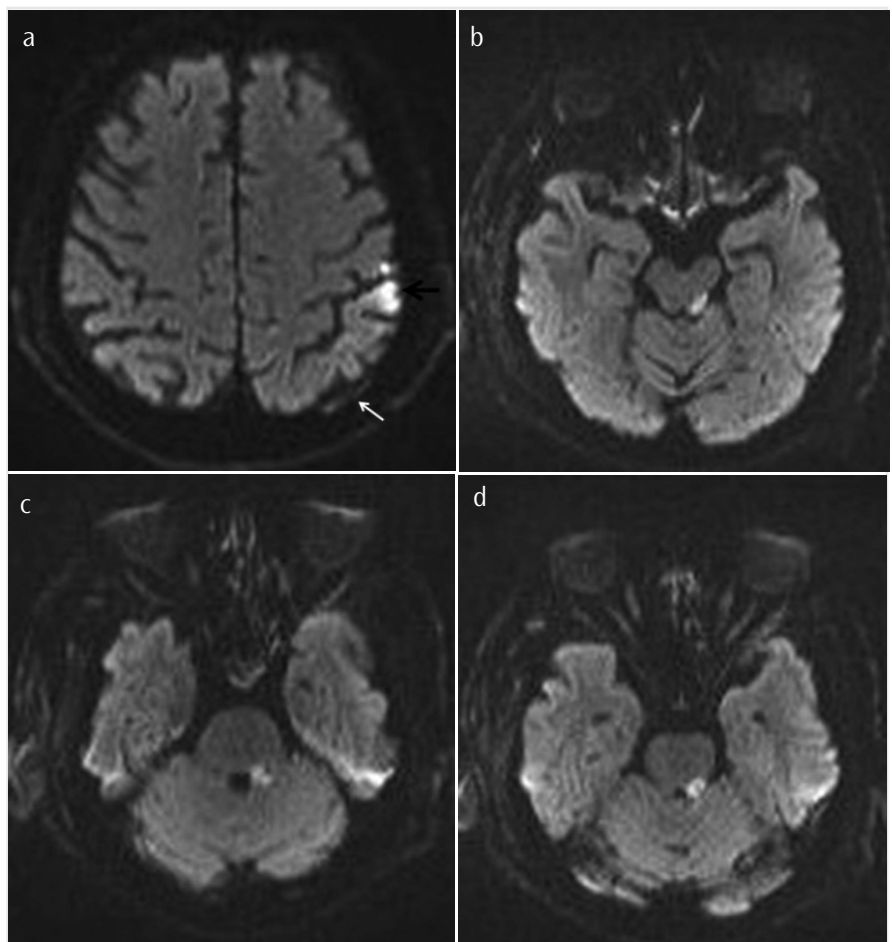

Figure 2. The diffusion-weighted image showing subdural haemorrhage in the left parietal region (a), and acute infarct areas in the left posterolateral regions of the mesencephalon (b) and pons (c), and at the level of the left superior cerebellar peduncle (d) with diffusion restriction in the left cerebellar hemisphere (a) that allows voluntary movements to be performed (3). Common causes of HOD include infarction, haemorrhage, arteriovenous malformation, tumour, trauma, previous surgery, inflammation, and demyelination (3). In addition, abscess, Wilson's disease, metronidazole toxicity, and neuro-Behçet's disease can cause HOD (4). Pathological changes that occur in HOD are characterised by neuronal growth and vacuolisation, astrocytic hyperplasia, demyelination, and gliosis. HOD is considered to occur secondary to the loss of afferent inputs to the inferior olivary nucleus (4). After the appearance of a destructive lesion within the Guillain-Mollaret pathway, HOD develops within weeks or months, and the pathological changes can last from three to five years $(2,5)$. On the T2-weighted and FLAIR images, HOD is seen as an expanding nodular lesion with an increased signal (about one month after the first lesion). No contrast enhancement or diffusion restriction occurs, and the condition is usually persistent (5). HOD is observed in three stages on the T2-weighted MRI images. In stage one covering the first six months, there is only hyperintensity of the lower olivary core. The second stage lasts from six months to three to four years and is characterised by hypertrophy and hyperintensity in the olivary core. The third stage starts with the resolution of the hypertrophy of the olivary core and persistence of the hyperintense signal and may continue indefinitely (6).

HOD clinically manifests with palatal myoclonus, ocular myoclonus, and tremor (3). Palatal tremor, also known as palatal myoclonus, is a typical finding of HOD and presents in the form of rhythmic, involuntary movements in the soft palate (3). If the primary lesion is confined to the tegmentum, the hypertrophic olivary nucleus becomes ipsilateral (5). If the primary lesion is located in the dentate nucleus or superior cerebellar peduncle, olivary degeneration develops contralaterally (5). Olivary degeneration is bilateral in the lesions occupying both the dentate nucleus and the tegmentum (5). Brainstem infarction, inflammatory diseases, and demyelinating and neoplastic diseases are investigated in

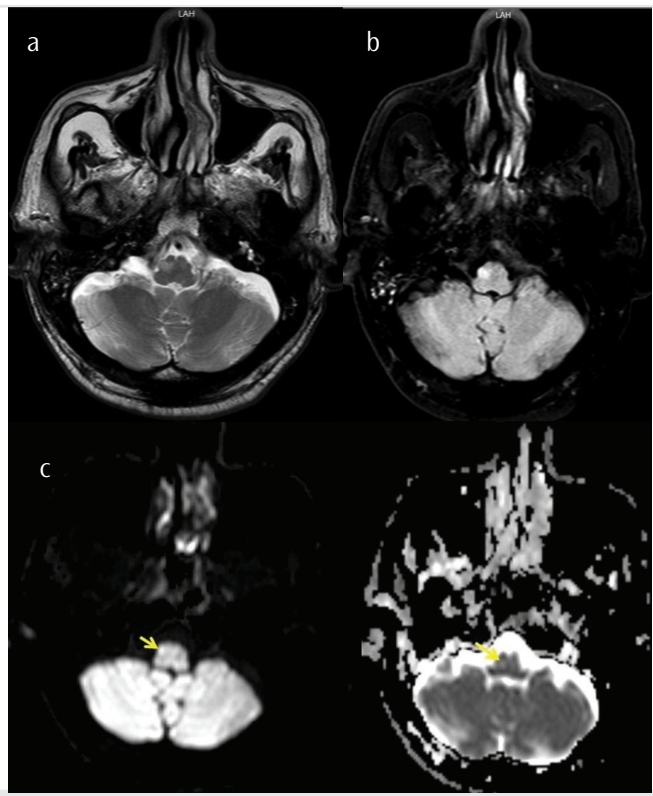

Figure 3. A nodular lesion in the olivary nucleus in the right medulla oblongata, which is hyperintense on T2-weighted (a) and FLAIR (b) images and shows no restriction in diffusion-weighted images and ADC maps (c)

FLAIR: fluid-attenuated inversion recovery, ADC: apparent diffusion coefficient 
the differential diagnosis of HOD (7). The lack of contrast enhancement in HOD helps to exclude some inflammatory and contrast-enhanced tumors (7). Hypertrophy of the nucleus is not a common finding in patients with demyelinating lesions and chronic infarction. Diffusion tensor imaging and magnetic resonance fibre tractography have been shown to be useful in demonstrating the impairment of the GuillainMollaret pathway (7).

\section{Conclusion}

HOD is relatively rare. Identification of HOD in MRI is very important because imaging findings are very similar to those of more serious pathologies, including tumours, infarction, demyelinating lesions, and infections. Having the knowledge concerning imaging characteristics can help to avoid unnecessary examinations and interventions for the patients.

\section{Ethics}

Informed Consent: Written informed consent was obtained from the patient.

Peer-review: Externally peer-reviewed.

Authorship Contributions: Concept- H.K., V.K.; Design- H.K., V.K., M.Ö.; Data Collection or Processing- H.K., A.T., B.H.; Analysis or InterpretationH.K., A.T., M.Ö., B.H.; Literature Search- H.K., V.K.; Writing- H.K.
Conflict of Interest: No conflict of interest was declared by the authors.

Financial Disclosure: The authors declared that this study received no financial support.

\section{References}

1. Kitajima M, Korogi Y, Shimomura O, Sakamoto Y, Hirai T, Miyayama H, et al. Hypertrophic olivary degeneration: MR imaging and pathologic findings. Radiology 1994; 192: 539-43.

2. Tilikete C, Desestret V. Hypertrophic Olivary Degeneration and Palatal or Oculopalatal Tremor. Front Neurol 2017; 8: 302.

3. Sabat S, Mannering N, Agarwal A. Hypertrophic olivary degeneration: case series and review of literature. J Neurol Sci 2016; 370: 180-6.

4. Konno T, Broderick DF, Tacik P, Caviness JN, Wszolek ZK. Hypertrophic olivary degeneration: a clinico-radiologic study. Parkinsonism Relat Disord 2016; 28 : 36-40.

5. Goyal M, Versnick E, Tuite P, Cyr JS, Kucharczyk W, Montanera W, et al. Hypertrophic olivary degeneration: metaanalysis of the temporal evolution of M R findings. AJNR Am J Neuroradiol 2000; 21: 1073-7.

6. Vattoth S, Ahmed F.Y, Telford R.C, Roberson G.H. Hypertrophic Olivary Degeneration: Review of Anatomy, Pathology, and Imaging. Neurographics 2014; 4: 114-22.

7. Shah R, Markert J, Bag AK, Curé JK. Diffusion tensor imaging in hypertrophic olivary degeneration. AJNR Am J Neuroradiol 2010; 31; 1729-31. 